\title{
RITUAL MAGI DI PADEPOKAN TJIMANDE TARI KOLOT KEBON DJERUK HILIR (TTKKDH) PONTANG DI DESA KESABILAN
}

\author{
Yanwar Pribadi, Anggun Cahyudin, Rita Setiawati, \\ Sofa Sofiyani, Nida Insani Fajri, Muhammad Huda, Lia Meila \\ Peneliti Fakultas Ushuluddin, Dakwah dan Adab \\ UIN Sultan Maulana Hasanuddin Banten \\ Email: sofasofiyani13@gmail.com
}

\begin{abstract}
Indonesian society is famous as religious society, which is wealthy about religiousness value more than confronted with culture combination with religion. From this matter, futhermore research beld to investigate society phenomenon particular in Banten region which is still thick in the mystical and magi science as soon as many people look at Banten as central practical magi science. Many variation magi science most found on and practicable by magi specialist in the Banten. This research on focus to magi phenomenon in the Persilatan Jtimande in the region Banten beach, Pontang. This research process to do with observation method reside magi ritual with cast about a proof along with inquiry data although field collecting. In this research will we can find out Banten history in the mystical and magi science at mentioned padepokan. This matter not loose from physical a proof when enter a field of study and must have historical base in the reference type as base reference.
\end{abstract}

Keywords: Phenomenon, Magi Ritual, Padepokan Tjimande, Banten, History.

\section{Abstrak}

Masyarakat Indonesia dikenal sebagai masyarakat religius, yang kaya akan nilai keagamaan terlebih ketika dibadapkan dengan penggabungan kebudayaan dengan agama. Dari hal ini, selanjutnya diadakan penelitian untuk mengkaji fenomena masyarakat khususnya di daerah Banten yang masih kental dalam ilmu mistis dan magi serta banyak orang yang memandang Banten sebagai pusatnya praktik ilmu magi. Berbagai jenis magi banyak ditemui dan dipraktikkan oleh para abli magi di Banten. Penelitian ini difokuskan pada fenomena magi 
dalam Persilatan Jtimande di daerah pesisir Banten, Pontang. Proses penelitian ini dilakukan dengan cara observasi lokasi bersemayamnnya ritual magi dengan mencari bukti serta data angket maupun data lapangan. ${ }^{1}$ Dalam penelitian ini nantinya kita bisa mengetahui sejarah Banten dalam ilmu mistis dan magi pada padepokan tersebut. Hal ini tidak lepas dari bukti fisik saat terjun lapangan dan harus mempunyai landasan bistoris dalam bentuk referensi sebagai acuan dasar.

Kata Kunci: Fenomena, Ritual Magi, Padepokan Tjimande, Banten, Sejarah.

\section{A. Pendahuluan}

Banten adalah provinsi yang ada di pulau Jawa yang berdiri pada tahun 2000 yang memiliki empat Kota dan empat Kabupaten dengan pusat perkotaannya atau Pusat Ibu Kota Provinsi Banten ialah Kota Serang sebagai administrasi daerah atau pusat pemerintahan daerah, Banten tidak lepas akan hal Agama dan Budaya khususnya peranan agama dan budaya melekat pada masyarakat Banten.

Mengkaji berbagai literatur tentang Banten baik dalam perspektif historis maupun antropologis-sosiologis, hampir selalu muncul citra Banten sebagai daerah yang religius menempatkan Islam menjadi agama mayoritas masyarakat Banten. Citra religius ini nampaknya bukan tanpa dasar dan alasan yang kuat. Dalam berbagai literature sejarah, ditemukan banyak data bagaimana Islam menjadi landasan yang kuat dalam beragama dalam berperilaku budaya masyarakat banten. ${ }^{2}$

Memahami kepercayaan terhadap dunia magi dan mistis merupakan pekerjaan yang paling sulit dilakukan. Padahal dua hal tersebut hampir selalu ada dalam fenomena kehidupan sosial keagamaan di hampir setiap budaya masyarakat di manapun dan menjadi bagian penting dalam setiap aktivitas kehidupan manusia sejak zaman dahulu sampai sekarang. ${ }^{3}$

Berbicara tentang magic, banyak ahli antropologi dan ahli sosiologi yang sering kali menghubungkan magic dengan agama dan sistem kepercayaan atau sebaliknya ketika 30.

1 Sugiyono, Metode Penelitian Kuantitatif, Kualitatif, dan RひB, (Bandung: Alfabeta), 2015, hlm.

2 Ayatullah Humaeni, Akulturasi Islam dan Budaya Lokal dalam Magi Banten, Jakarta: UIN Syarif Hidayutullah), 2013, Sinopsi. hlm. 3.

3 Ayatullah Humaeni, Teori Magi dan Mistis (Sebuah pengantar Antropologi Agama dan Budaya), (Banten: Dinas Pendidikan), 2012, hlm. 1. 
membahas tentang agama dan system kepercayaan sering kali magic menjadi salah satu konsep yang sering dikaitkan dengan bentuk awal sebuah kepercayaan manusia terhadap keyaninan agama dan sistem kepercayaan. ${ }^{4}$

Magi adalah sebuah fenomena sosial yang nyata yang terdapat baik pada masyarakat pre-literate maupun masyarakat modern. Oleh karenanya, hampir setiap masyarakat percaya bahwa magi itu betul-betul ada dan terjadi dalam area kehidupan mereka dan mereka percaya bahwa situasi-situasi sosial bisa dipengaruhi,diubah, disembuhkan, dihancurkan, dan di transformasikan dengan tindakan-tindakan magi. Dalam hal ini, Malinowski beragumen bahwa magi bisa membangun kepercayaan dalam situasi-situasi yang tidak pasti ${ }^{5}$

Oleh karena masih kuatnya kepercayaan masyarakat banten terhadap hal-hal mistis dan magi, maka tidak heran jika kemudian banyak orang yang memandang Banten sebagai pusatnya praktik ilmu magi. Berbagai jenis magi banyak dimiliki dan dipraktikkan oleh para ahli magi di Banten. ${ }^{6}$

Citra Banten sebagai salah satu tempat bersemayamnya ilmu-ilmu magis (the beaven of occult sciences), sebagaimana yang pernah diungkapkan oleh Martin Van Bruinessen dalam karyanya Kitab Kunin, Pesantren, dan Tareka: Tradisi-tradisi Islam di Indonesia, masih dapat dilacak keberadaannya sampai saat ini pada masyarakat banten. ${ }^{7}$ Salah satu tempat yang diduga menjadi tempat mentradisikan budaya Magi adalah Padepokan Silat (debus). Debus tidak lepas dengan agama dan budaya dalam aplikasinya debus selalu diidentikkan dengan kekuatan dan kekebalan (kebatinan), kebatinan secara terminologi adalah suatu pandangan hidup yang mempercayai kepada Tuhan Yang Maha Esa untuk menuju budi luhur dan kebahagian hidup ${ }^{8}$ ketika pratik debus dilakukan untuk mendekatkan diri pada sang penciptanya. hlm. 3 .

${ }^{4}$ Ayatullah Humaeni, Teori Magi dan Mistis (Sebuah pengantar Antropologi Agama dan Budaya)...,

5 Ayatullah Humaeni, Akulturasi Islam dan Budaya Lokal dalam Magi Banten, Jakarta: UIN Syarif Hidayutullah), 2013, hlm. 5.

6 Ayatullah Humaeni, Akulturasi Islam dan Budaya Lokal dalam Magi Banten..., hlm. 3.

7 Sholahuddin Al Ayubi, MAGI Di Lingkungan Pesantren (Studi Magi Kitab Mujarrabat alDairabi al-Kabir di Pondok Pesantren Salafiyah Banten), (Banten, Serang: FUDAPress), 2012 cet.1, hlm. 1. hlm. 29 .

${ }^{8}$ Syafi'in Mansun, KULIAH Aliran Kebathinan, (Banten, Serang; FUDAprees), 2009, Cet. 1 
YANWAR PRIBADI dkk

Sejak masa pra-Islam di Nusantara, kekebalan dan kesaktian merupakan sarana penting individu untuk mencapai cita-cita luhurnya untuk berkuasa sehingga keduanya banyak dicari. Legenda-legenda tentang para wali serta kemenangan Islam seringkali dihubungkan dengan kesaktian individu yang wali, kesaktian ini dipercaya berkat keunggulan zikir dan wirid ketimbang mantra dan jampi-jampi Hindu-Buddha. Karena itu, banyak orang yang yang beranggapan bahwa pesatnya perkembangan Islam pada masa-masa awal di Nusantara adalah melalui jalur Tasawuf, karena ajarannya yang dekat dengan budaya Masyarakat Nusantara selama ini. Kecenderungan seperti ini Akhirnya menjadikan tarekat (salah satu bagian praktik tasawuf yang terorganisir) banyak di gandrungi Masyarakat karena dalam tarekat mereka akan diajarkan wirid dan zikir yang dapat membangkitkan kesaktian individu. Bukan saja tarekat Qodariyah, amalan semua tarekat yang lain juga dipakai untuk mengembangkan kesaktian dan kekebalan, seperti Rifai'yah, Samaniyah, dan Khalwatiyah. ${ }^{9}$

Lalu bagaimana praktik magi ini dilakukan dalam tradisi kesenian, Praktik magi tidak lepas dari ritual khusus untuk mendapatkan kekuatan (kesaktian dan kekebalan) di dalam ilmu tarekat sehingga seseorang individu atau kelompok yang ingin mendapatkan ilmu kebatinan harus melakukan ritual ini, ritual adalah teknik (cara, metode, praktik) yang dijalankan baik individu maupun kelompok dimana mempunyai pimpinan sebagai sarana magi. ${ }^{10}$

Hal ini pun terjadi di Desa Kesabilan Kecamatan Pontang Kabupaten SerangBanten. Dimana terdapat Padepokan Tjimande Tari Kolot Djeruk Hilir (TTKKDH) tidak lepas dari mistis dan magi serta ritual sebagai saranatnya. karena dalam hal praktik kesenian ini tidak lepas dengan praktik-praktik ritual magi, kesenian ini sering kali kita menyebutnya dengan Pencak Silat. Fenomena ini yang menarik perhatian penulis untuk mengangkatnya sebagai bahan penelitian untuk tugas kelompok

\footnotetext{
${ }^{9}$ Sholahuddin Al Ayubi, MAGI Di Lingkungan Pesantren (Studi Magi Kitab Mujarrabat al-Dairabi al-Kabir di Pondok Pesantren Salafiyah Banten), (Banten, Serang: FUDAPress), 2012 cet.1 hlm. 3. 29.

${ }^{10}$ Sholahuddin Al Ayubi, Agama dan Budaya, (Banten, Serang: FUD Prees) 2009, cet $1 \mathrm{hlm}$.
} 
Fenomena ini terjadi di kampung tersebut dan menarik untuk diteliti, bagaimana hal itu terjadi manakala ritual praktik magi ini dilakukan dalam kesenian Pencak Silat yang di identikan dengan ilmu Kebatinan dalam praktik seninya.

Hal ini yang mendasari penulis untuk melakukan penelitian tersebut.selain praktik magi yang dilakukan yang menjadi dasar penelitian yang ingin di kaji, juga terkait dengan hubungan ilmu tarekat untuk melihat dari sisi sentimen ilmu Tasawuf.

\section{B. Kondisi Lokasi Penelitian}

\section{A. Sejarah/Asal-Usul Tempat}

Desa Kesabilan adalah desa yang berada di Kecamatan Pontang arah utara sebelum desa domas, yang berada dekat di hulu sungai pontang, asal muasal kesabilan, dari kata "kesa" yang artinya "tawar" dan "bilan" yang artinya “mengalir" yang di artikan air sungai dekat muara ini airnya tawar, fenomena alam ini tidak lepas dari cerita rakyat, yang biasanya rasa air akan mengikuti letak geografisnya, sedangkan desa kesabilan dekat dengan bibir pantai serta pertemuan sungai dengan air laut, akan tetapi fenomena ini terbalik, konon cerita dulu ada seorang kiyai yang sakti mandra guna melewati daerah tersebut dan bertemu pada masyarakat kesabilan, dan mengatakan bahwa sumber mata air di sini terasa tawar karena mengikut daerah selatan walau dekat dengan laut airnya terasa tawar tidak berasin yang seharusnya asin. ${ }^{11}$

\section{B. Kondisi Demografis (Kependudukan)}

Kondisi demografis yang ada di daerah pontang tersebut khususnya desa kesabilan, menurut data sekunder kependudukan terdapat 600 kepala rumah tangga di tahun 2016 dengan sensus dewasa dewasa 65\% remaja serta anakanak 20\% manula 15\% dengan rumah permanen dengan ruas rata-rata rumah 15x10 meter dengan sudut dermaga 3 meter serta ruas jalan utama 3,5 meter. Dengan rata-rata jalan setiap gang 1,5 meter. ${ }^{12}$

\section{Kondisi Perekonomian}

Pada masyarakat pontang khususnya masyarakat desa Kesabilan, dalam pengasilan yang didapat berasal dari pertanian, padi ialah salah satu

11 Suparni (70) desa Kesabilan Pontang.

${ }^{12}$ Data sekunder kelurahan kesabilan, Rudi Sutandi (45) Kepala Desa Kesabilan. 
pendorong ekonomi pada masyarakat kesabilan dalam satu tahun diadakan tiga kali panen dalam setahun dengan 1500 ton padi dalam satu panen, bukan hanya petani sebagai pengahasil ekonomi tatpi pula banyaknya pertumbuhan remaja bekerja di salah pabrik di setiap wilayah Kabupaten Serang. Dengan rata-rata penghasilan 2.500.000,-, perikanan pekerjaan sampingan di waktu tertentu dimana pertambakan ikan dengan penghasilan satu juta per bulan. Lemahnya kependidikan yang mengakibatkan jarangnya usia remaja tidak melanjutkan sekolah diakibatkan faktor ekonomi, sehingga masyarakat kesabilan jauh dari pendidikan dalam sarjana satu.

\section{Pengertian Ritual Magi}

Sejak masa pra-Islam di Nusantara, kekebalan dan kesaktian merupakan sarana penting dari individu untuk mencapai cita-cita luhurnya untuk berpuasa sehingga keduanya banyak dicari. Legenda-legenda tentang para wali serta kemenangan Islam sering kali dihubungkan dengan kesaktian individu sang wali, kesaktian mereka ini di percaya berkat keunggulan zikir dan wirid ketimbang mantra dan jampi-jampi Hindu-Buddha. Karena itu, banyak orang yang beranggapan bahwa pesatnya perkembangan Islam pada masa-masa awal di Nusantara adalah melalui jalur tasawuf, karena ajarannya yang dekat dengan budaya masyarakat Nusantara selama ini. Kecenderungan seperti ini akhirnya menjadaikan tarekat (salah satu bagian praktik tasawuf yang terorganisir) banyak digandrungi masyarakat karena dalam tarekat mereka akan di ajarkan wirid dan zikir yang dapat membangkitkan kesaktian individu. Bukan saja Tarekat Qodariyah, amalan semua tarekat yang lain juga dipakai untuk mengembangkan kesaktian dan kekebalan, seperti Rifai'yah, Samaniyah dan Khalwatiyah. ${ }^{13}$

Ritual adalah salah satu praktik dalam adat-istiadat kebudayaan.ritual ialah teknik (cara, metode, praktik) membuat suatu adat kebiasaan menjadi suci (sanctify the custom). Ritual menciptakan dan memelihara mitos, juga

13 Sholahuddin Al Ayubi," Magi Lingkenngan pesantren”, (FUDA IAIN Banten), 2012, hlm. 3. 
adat sosial dan agama. Ritual bisa pribadi atau berkelompok. Wujudnya bisa berupa doa, tarian, drama, kata-kata seperti “Aamiin".

Menurut Riaz Hasan, ritual merupakan bagian integral dari agama formal. Yang mencangkup praktik-praktik keagamaan termasuk ibadah dan hal-hal yang dilakukan manusia dalam melaksanakan perintah agamanya. ${ }^{14}$ Satu di antara ritual yang paling kuno adalah ritual magi.

Magi adalah sebuah fenomena sosial yang nyata yang terdapat baik pada masyarakat sebelum kesusastraan maupun masyarakat modern oleh karenanya, hampir setiap masyarakat percaya bahwa magi itu betul-betul ada dan terjadi dalam area kehidupan mereka dan mereka percaya bahwa situasisituasi sosial bisa dipengaruhi, diubah, disembuhkan, dihancurkan, dan diubahkan dengan tindakan-tindakan magi. Dalam hal ini, Marlionowski beragumen bahwa magi bisa membangun kepercayaan dalam situasi-situasi yang tidak pasti.

Menurut kamus besar bahasa Indonesia magi yaitu suatu cara tertentu yang diyakini dapat menimbulkan kekuatan ghaib dan dapat menguasai alam sekitar termasuk alam pikiran dan tingkah laku manusia. ${ }^{15}$

Meskipun terdapat beragam indikasi adanya proses akulturasi Islam dan budaya lokal dalam tradisi magi di Banten, namun dalam banyak hal, terutama dalam aspek beribadat, muamalat, dan tradisi sosial keagamaan lainnya, menurut Michrob, esensi Islam secara normatif masih berlaku pada masyarakat banten, sementara adaptasi itu hanya berlaku pada level tradisi kultural. Dalam hal ini, Ambary, sebagaimana dikutip oleh Michrob, juga menyatakan bahwa kelanjutan tata cara ritual magi. ${ }^{16}$

Dalam peneltian ini menurut pendapat masyarakat Kesabilan Desa Pontang, bernama Ahmad Suandi (kang Mamak) menyatakan ritual magi di dalam padepokan Tdimande Tari Kolot Djeruk Hilir ritual adalah salah satu pendekatan diri untuk keselamatan serta pendekatan diri kepada sang

\footnotetext{
${ }^{14}$ Sholahuddin Al Ayubi, "Agama dan Budaya", (FUDA IAIN Banten), 2009, hlm. 41.

${ }^{15} \mathrm{KKBI}$ pengertian Magi.

16 Ayatullah Humaeni, "AKulturasi Islam dan Budaya local dalam Magi Banten", (UIN Syarif
} Hidayatullah Jakarta), 2013, hlm. 5. 
Penciptanya yaitu melalui kegiatan olah batin sebagai satu syarat untuk mengikuti ilmu kebatinan. ${ }^{17}$

A. Hubungan ritual magi dengan Islam

Dalam ritual magi yang dilaksanakan di Persilatan Tjimande merupakan bentuk ritual yang mengarah kepada unsur keIslaman, sebab dalam ritual magi di persilatan tersebut telah menetapkan syahadat dalam ketentuan awal masuk persilatan (perjanjian). Selain itu pendirinya pun juga berlatar belakang agama Islam, yaitu Mbah Khohir, Mbah Kholiah, Mbah Hayah Khursi, Mbah Endut, Mbah Main, Mbah Buyah, Mbah Ranggawulung.

Disebutlah 7 perguruan yang mempunyai persilatan. Mereka tersebut adalah pendiri dari silat Tjimande yang berasal dari Jawa Barat, yaitu bogor awal mula berdirinya padepokan persilatan Tjimande.

Tujuan dari 7 pendiri ini bukan hanya mendirikan dunia persilatan saja akan tetapi juga sebagai salah satu metode dakwah kepada masyarakat yang belum mengenal Islam yaitu pada dasarnya untuk mengajak masyarakat yang melalui metode tersebut bahwa kekuatan Allah dapat dibuktikan. Hubungan ritual magi dengan keIslaman lainnya, yaitu untuk menjaga dan menjalin silaturahmi antarsesama, sebab dalam Islam pun telah diajarkan.

\section{Perkembangan Ritual Magi di Persilatan Tjimande}

Dalam perkembangan ritual magi di persilatan tjimande tersebut pada mulanya berawal dari daerah Jawa Barat yang terdapat didaerah Bogor yang pada dasarnya untuk menyebarkan agama Islam. Selanjutnya, dengan adanya persilatan tersebut telah banyak pengikut dari daerah tersebut maupun daerah luar salah satunya Banten. Dengan penyebaran ini dapat dipastikan penyebaran Islam di luar daerah Bogor telah dicapai. Riwayat sebelum mendirikan sebuah perguruan bernama Penca Cimande, Ayah Kahir pernah tinggal dan mengajarkan ilmunya di kota Kabupaten Cianjur. Di kota ini pada

${ }^{17}$ Ahamd Suandi (33 tahun) ketua padepokan TTKDH Pontang. 
tahun 1770 ia menikahi seorang wanita setempat dan bermukim di Kampung Kamurang, Desa Mande, Cianjur. Di kampung ini pula Ayah Kahir mengajarkan maenpo atau penca kepada para pemuda setempat.

Ketenarannya sebagai guru penca menyebabkan bupati Cianjur Aria Wiratanudatar IV atau Dalem Cikundul (1776-1813) memintanya untuk mengajarkan maenpo kepada putera-putera bupati, pegawai kabupaten dan para petugas keamanan. Tahun 1815, Ayah Kahir ke Bogor dan menetap di Kampung Tarikolot, Desa Cimande Kecamatan Caringin Kabupaten Bogor. Di Bogor ini pula ia meninggal dunia pada tahun 1825.

Sebelum dikenal sebagai guru silat, Abah Kohir atau Embah Kohir terkenal sebagai ahli kebatinan di kota Kabupaten Cianjur. Kepandaiannya bermain penca diketahui melalui adu laga dengan seorang Cina yang berasal dari Makao yang mahir beladiri Kuntao (salah satu jenis beladiri yang berasal dari dataran Tiongkok).

Dikisahkan bahwa pada suatu hari ada orang Cina yang melanggar ketertiban umum, maka ia kemudian ditangkap oleh petugas Kabupaten Cianjur. Dalam penangkapan itu, orang Cina tersebut melakukan perlawanan, melecehkan petugas dan menantang adu laga dengan siapa saja. Pada waktu itu petugas keamanan kewalahan dan tidak bisa berbuat banyak.

Ayah Kohir atau Embah Kohir kemudian diminta oleh bupati Cianjur untuk meladeni tantangan orang Cina tersebut sekaligus menangkapnya. Ayah Kohir menyanggupi permintaan bupati, maka dilakukanlah pertarungan di alun-alun kabupaten disaksikan oleh bupati dan masyarakat kota Cianjur. Dalam pertarungan itu, Ayah Kohir dapat mengalahkan orang Cina tersebut dan menyerahkannya kepada bupati. Melihat keberhasilan itu, bupati kemudian meminta Ayah Kohir untuk melatih penca para petugas keamanan Kabupaten Cianjur.

Dikisahkan selanjutnya, beberapa waktu kemudian di Kabupaten Bogor sedang terjadi kerusuhan. Bupati Bogor meminta untuk kesediaan Ayah Kohir untuk membantu memadamkan dan menumpas perusuh. Atas persetujuan bupati Cianjur, Ayah Kohir kemudian ke Bogor dan kerusuhan dapat dipadamkan. Atas keberhasilan ini beliau kemudian diminta 
mengajarkan penca kepada para petugas keamanan. Selama di Bogor Ayah Kohir atau Embah Kohir bermukim di kampung Tarikolot dekat Sungai Cimande, di sana ia mengajarkan penca kepada masyarakat umum dan mendirikan perguruan Cimande. Perguruan kemudian diserahkan kepada keturunannya (?) dan ilmu silat ini kemudian tersebar.

Ayah Kohir kemudian pindah dari Kampung Tarikolot ke kota Kabupaten Bogor ke suatu tempat bernama Tanah Sereal dimana akhirnya beliau meninggal dunia di sana. Mengungkapkan kisah penemuan jurus tersebut. Mbah Khaer (sebutan lain Ayah Kahir) pada suatu waktu di subuh hari hendak mencuci beras sekaligus berwudlu ke sebuah talang (saluran air) di sisi Sungai Cimende. Ia berbekal sebuah boboko berisi beras (wadah tempat mencuci beras) dan sebuah lampu/pelita untuk menerangi perjalannya ke talang tersebut. Sesampai di dekat talang, ia melihat suatu pemadangan aneh yang baru pertama kali dilihatnya. Di depannya sedang berlangsung pertarungan sengit 2 ekor hewan yaitu seekor harimau dengan seekor monyet.

Dalam perlihatannya bagaimanapun harimau tersebut berusaha menekan sang monyet tetapi selalu berhasil dielakkan, demikian pula sang harimau selalu berhasil menangkis serangan gencar sang monyet. Kedua binatang ini tidak menyadari bahwa tingkah laku mereka sedang diperhatikan dengan seksama oleh seorang manusia. Hingga akhirnya pertarungan tersebut selesai tanpa menimbulkan luka berarti pada keduanya dan mereka kabur berlainan arah. Mbah Khaer segera mencuci berasnya dan setelah berwudlu ia cepat-cepat kembali ke rumah karena ia teringat bahwa suaminya selalu pulang pada pagi hari.

Dalam kisah ini Mbah Khaer diriwayatkan sebagai seorang wanita yang mempunyai tugas sebagaimana halnya seorang isteri yaitu mempersiapkan sarapan bagi suaminya. Sesampai di rumah ternyata sang suami telah menunggu dengan muka marah, dan tanpa bertanya apa-apa sang suami langsung menyerang isterinya. 
Suaminya merupakan jawara di kampung tersebut yang pekerjaannya pergi malam pulang pagi, sering mabuk-mabukan dan berjudi. Sedangkan sang istri adalah seorang santri dan ibu rumah tangga. Mendapat serangan tiba-tiba dari suaminya, Mbah Khaer spontan berkelit mengikuti gerakan monyet yang dilihatnya bertarung tadi.

Penasaran dengan serangannya yang gagal kembali sang suami menyerang dengan pukulan dan tendangan. Mbah Khaer sambil menggendong boboko berisi beras terus berkelit menghindari serangan suaminya tanpa sekalipun membalas meskipun selalu ada kesempatan untuk itu. Apa yang dilihatnya di talang tadi ternyata memberi ilham baginya untuk menghindar dan menangkis serangan sang suami. Sang suami akhirnya menghentikan serangannya karena kelelahan ditambah rasa penasaran akan kemampuan istrinya yang dapat dengan mudah menghindari semua seranganserangannya. Padahal ia terkenal sebagai seorang jawara di tempat itu.

Akhirnya ia mengaku takluk dan mengemukakan niat untuk mempelajari jurus-jurus tersebut kepada istrinya. Singkat cerita sang istri kemudian mengajarkan jurus-jurus tersebut dan sang suami adalah murid pertamanya.

Dalam perkembangan aliran penca Cimande yaitu setelah para murid menyelesaikan pendidikan di Bogor, mereka kemudian menyebar dan ada yang kembali ke daerah asal mereka masing-masing. Embah Buyah salah seorang murid Embah Main kemudian kembali ke Kampung Oteng di Kecamatan Warunggunung Kabupaten Lebak, selanjutnya melakukan petualangan ke daerah Lampung Peristiwa ini diperkirakan berlangsung dalam tahun 1948.

Embah Buya yang orang asli Kabupaten Lebak, sebelum berguru kepada Embah Main berprofesi sebagai pedagang tembakau yang menjual dagangannya ke Karawang. Di Karawang Embah Buya kemudian menikah dengan wanita Karawang bernama Asten yang juga adalah murid Cimande Mbah Main atau dikalangan warga Cimande (sebutan bagi murid Cimande) disebut Ibu Asten (wawancara dengan Agus Suganda) atau Embah Dosol (wawancara dengan Bapak Husin dan Bapak Ahmad Fatoni). 
Embah Buyah menerima pendidikan penca Cimande dari Embah Main yang mendirikan pusat pelatihan di kebun jeruk beliau di sebelah hilir, dimana Embah Main memiliki 2 buah kebun jeruk satu di girang satunya di bilir. Sebutan girang dan hilir merujuk pada posisi suatu tempat yang berada pada posisi di atas dan di bawah. Jadi kebun jeruk hilir adalah menunjukkan letak kebun tersebut di posisi lebih rendah dari kebun jeruk lainnya.

Embah Buyah kemudian melanjutkan pengembangan penca Cimande di Lampung dengan membuka paguron yang menerima murid khusus orangorang Jawa. Penerimaan murid dari kalangan orang Jawa dilatarbelakangi suatu kisah seperti yang dituturkan oleh Agus Suganda bahwa suatu waktu ada orang Melayu Lampung berniat berguru kepada beliau, ternyata kemudian si orang Melayu tersebut hanya ingin menguji kemampuan Embah Buyah. Embah Buyah tidak menyenangi hal itu sehingga beliau kemudian mengusir orang tersebut bahkan kemudian beliau menyatakan tidak akan mau menerima orang Melayu yang berasal dari Lampung.

Paguron Cimande Embah Buyah di Lampung kemudian diberi nama Tjimande Tarikolot Kebon Djeruk Hilir. Tampaknya Embah Buyah memberi nama paguronnya didasari tanda bakti beliau kepada pendiri dan guru penca beliau, dimana pendiri penca Cimande yaitu Embah Khaer mendapatkan ilmu silatnya di Kampung Tarikolot dekat Sungai Cimande, kemudian penamaan Kebon Djeruk Hilir mengadopsi nama tempat Embah Buyah menerima ilmu penca Cimande dari Embah Main, gurunya.

Tahun 1951 dibuatlah suatu aturan hukum yang sifatnya mengikat kepada seluruh warga T'TKKDH yang disebut pertalekan Cimande. Tujuannya adalah sebagai pengarah tertulis bagi murid sekaligus penjaga nama baik bagi TTKKDH itu sendiri. Pada tahun 1953, Embah Buyah kembali ke Kampung Oteng dan mendirikan paguron TTKKDH di sana.

Meski tidak diperoleh informasi tepatnya Embah Buyah meninggal dunia, namun TTKKDH terus berkembang sepeninggal beliau. Muridmuridnya meneruskan tradisi dan paguron TTKKDH dan sejak ditangani 
oleh Embah Ranggawulung nama TTKKDH melekat sampai sekarang pada perguruan silat Cimande ini.

TTKKDH adalah bahwa penamaan Tjimande Tari Kolot Kebon Djeruk Hilir mengandung maksud semacam falsafah bagi setiap warga Cimande. Tjimande mengandung 2 pengertian yaitu kata Tji dalam bahasa Sunda berarti air dan mande berarti suci. Tari dikonotasikan dengan tanya atau pertanyaan. Kolot mengandung makna sesepuh atau orang yang dituakan ada juga yang mengartikan sebagai kata kesti atau membudayakan kebenaran.

Kebon adalah suatu lahan pekerjaan untuk mendapatkan hasil yang halal atau bermakna wadah untuk mencapai keselamatan. Djeruk diartikan sesuai bentuk dan rasanya yaitu bentuk besar berarti manis, bulat berarti bersatu dalam satu wadah, dan kulitnya yang terasa pahit diartikan sebagai barang yang tidak bermanfaat.

Hilir mengandung makna harus selalu merendahkan hati tidak sombong dan mengalah untuk menang, hilir yang berposisi di bawah juga diartikan sebagai tempat menampung apa saja kemudian disaring dan mengambil yang bermanfaat. Hilirpun juga diartikan penyelesaian masalah dengan musyawarah).

Tjimande Tari Kolot Kebon Djeruk Hilir secara luas mempunyai pengertian. Dalam kehidupan selalulah berusaha mendapatkan sesuatu dari pekerjaan yang halal, dan jika menghadapi suatu masalah selesaikan dengan musyawarah atau meminta bimbingan kepada sesepuh atau orang yang mengerti permasalahan tersebut serta seyogyanya untuk selalu bantumembantu (gotong royong) dalam melaksanakan kepentingan bersama. Pengertian di atas menempatkan TTKKDH sebagai alat pemersatu dengan misi utama menghindarkan diri dari perbuatan-perbuatan yang merugikan individu maupun masyarakat.

TTKKDH juga memiliki ciri khas lain yaitu adanya prinsip “jika terpegang, kita memegang”. Paguron Cimande lainnya (disebut Cimande Girang) memilki prinsip lain yaitu "bila terpegang menyerang". Prinsip TTKKDH lainnya adalah di setiap latihan selalu ada nyala lampu (pelita), ini dijadikan syarat pelatihan yang juga mengikuti perbuatan Embah Khaer 
ketika ia pegi ke tepi sungai Cimande. Oleh karena itu awal latihan Cimande bagi murid baru selalu dimulai pada malam hari terutama Kamis malam.

Dalam riwayat lahirnya Penca Cimande dikisahkan bahwa Embah Khaer mengadopsi gerakan tarung dua ekor binatang yaitu Harimau dan Kera. Menurut penuturan Agus Suganda, pada awal pelatihan atau sebelum terbentuknya TTKKDH belum ada istilah jurus-jurus Cimande, bahkan paguron resmi bernama Cimande pun belum ada, yang ada adalah jurus pamacan dan pamonyet yaitu pengembangan gerakan jurus serang-elak yang berasal dari tingkah kedua binatang tersebut. Setelah terjadi perkembangan yaitu setelah masyarakat menerima penca Cimande ini, terjadilah persebaran ke seluruh Jawa Barat dan Banten kemudian menyebar ke seluruh Indonesia. Dari segi teknik, jurus-jurus Cimande ada yang mengalami perubahan, namun demikian perubahan tersebut tidak sampai menghilangkan jurus dalam Cimande.

Pada TTKKDH, jurus-jurus Cimande disusun secara berurut dengan jumlah gerak jurus 19 buah dan 1 jurus tanpa gerak atau "rahasia" atau aya wenangan (Agus Suganda). Diantara kesembilan belas jurus TTKKDH tersebut adalah Kelid Gede, Kelid Leutik, Po Jero, Po Luar, Selut, Timpa Sebelah, Gojrok, Getrak Lubur, Getrak Handap, Kepretan, dan Guntingan. Adapun jurus ke duapuluh atau jurus rahasia tersebut disebut demikian karena sifatnya lebih mengarah kepada aspek kerohanian yaitu kematangan seorang murid Cimande menyebabkan ia mampu mengendalikan diri atau bersifat seperti padi. Artinya jurus terakhir ini dikembalikan kepada sang murid sendiri untuk mencapai dan mengolahnya, sepanjang tidak bertentangan dengan Talek Cimande.

Sejak didirikan pada tahun 1953, TTKKDH wilayah Kabupaten Lebak terus mengalami perkembangan demikian pesat sampai saat ini. Kemudian meskipun tidak ada kepastian tentang jumlah muridnya, namun sepanjang pengamatan penulis baik ketika penulis masih berstatus sebagai tenaga SP3K di Kecamatan Cimarga Kabupaten Lebak (1995-1997) dan 
ketika penelitian ini laksanakan (2002), jumlah murid TTKKDH cenderung mengalami penambahan. Hal ini terjadi karena TTKKDH memiliki pola perekrutan murid baru yang cukup unik yaitu pada saat acara keceran sering ditampilkan atraksi berupa ibingan atau igelan yaitu pergelaran tarian silat yang diiringi musik tradisional. Meskipun sederhana, alat-alat musik yang terdiri dari gendang, terompet, dan gong mampu memukau penonton ditambah atraksi tarung silat yang diperagakan jawara-jawara TTKKDH. Dari kondisi ini kemudian menimbulkan daya tarik bagi penonton yang belum menjadi warga TTKKDH. Agus Suganda menyebutkan setiap bulan ada sekitar 3 sampai 5 orang yang masuk menjadi murid diluar keluarga para jawara TTKKDH. Oleh karena itu sangatlah sulit untuk mencatat jumlah pasti murid-murid tersebut, sebab disetiap desa sebagai wilayah ranting TTKKDH di Kabupaten Lebak selalu ada beberapa keluarga TTKKDH yang artinya selain orang tuanya, anak-anaknya juga menjadi murid TTKKDH dan Agus Suganda menjamin mereka bisa ditampilkan kapan saja. Tampaknya regerasi penurunan ilmu Cimande versi TTKKDH terus berjalan sampai saat ini.

Dalam perkembangannya Cimande yang dulu diklaim sebagai milik etnis Sunda (Jawa Barat dan Banten) kemudian menasionalisasikan diri dengan melakukan persebaran ke hampir seluruh wilayah Indonesia. Mbah Buyah yang menerima Cimande dari Mbah Main di Karawang melanjutkan pengembangan dengan mendirikan TTKKDH justru di luar wilayah Jawa Barat dan Banten yaitu di Lampung yang dikenal sebagai daerah orang-orang Melayu.

Lebih jauh dari itu pencak Cimande tidak hanya berada di Indonesia, mancanegara juga turut mengembangkannya dengan memakai pelatih-pelatih dari aliran Cimande Indonesia seperti Perguruan Pajajaran Nasional yang didirikan oleh Sidik Sakabrata di Belanda atau Perguruan Pencak Silat Mande Muda yang didirikan oleh Herman Suwanda di Amerika Serikat. ini mengindikasikan bahwa budaya leluhur bangsa Indonesia tersebut diterima berbagai pihak dan berbagai kalangan.

TTKKDH tidak pernah melakukan promosi khusus untuk menerima murid baru, mereka para calon murid datang sendiri kemudian diperlihatkan 
Talek Cimande dan diberikan pengarahan seperlunya tentang TTKKDH, setelah itu keputusannya diserahkan kembali kepada mereka apakah tetap mau masuk menjadi murid atau tidak. Demikian ungkapan Agus Suganda tentang pola perekrutan murid bagi TTKKDH.

Biasanya setelah diberikan informasi mereka menyatakan persetujuannya, lanjutnya. Ini berbeda dengan beberapa perguruan silat lain yang melakukan promosi secara langsung untuk menerima murid baru, misalnya perguruan Santria Nusantara (perguruan ini lebih mengarah kepada teknik penyaluran dan pemanfaatan nafas terutama untuk pengobatan, tetapi dimasukkan sebagai anggota IPSI) yang secara berkala melakukan promosi melalui berbagai media.

Bagi TTKKDH calon murid tidak perlu dipanggil, mereka akan datang sendiri untuk berlatih setelah persayaratan disetujui. Jadi sifatnya adalah kesiapan calon murid diutamakan sedangkan kesiapan pelatih selalu tersedia. Ini dimungkinkan sebab pelatihan TTKKDH berlangsung di malam hari dimana biasanya jawara TTKKDH melakukan aktivitas rutin di siang hari dan pada malam harinya mereka beristirahat jika sedang tidak berlatih. Apalagi bila tiba malam Jumat (Kamis malam) yang merupakan malam wajib latih bagi murid TTKKDH.

Adapun mengenai jumlah murid TTKKDH bukan dari sebuah keluarga melainkan juga berasal dari lingkungan luar keluarga. Bukan berarti tidak ada catatan tentang sang calon murid, sebab sebelum resmi menjadi murid, calon murid diharuskan mengisi semacam formulir yang sebenarnya adalah biodata. Tujuannya adalah untuk mengetahui data diri murid tersebut. Alasan penggunaan biodata ini lebih bersifat informal yaitu untuk kebutuhan sang pelatih sendiri bahwa dia telah mengajar simurid. Bagi sang murid boidata tersebut dapat menjadi bukti bahwa dia juga warga TTKKDH yang mendapat pengajaran dari gurunya tersebut.

Pada saat ini pusat TTKKDH yang berada di kota Serang telah membuat kartu anggota mempunyai masa waktu 2 tahun, tetapi belum semua 
murid TTKKDH mendapatkan fasilitas tersebut. Penggunaan masa berlaku kartu 2 tahun mengandung maksud bahwa dalam masa tersebut sang murid atau warga TTKKDH belum melanggar Talek Cimande. Juga menjadi pertimbangan (semacam ikatan waktu meskipun dibuat selonggar-longgarnya) bagi murid TTKKDH untuk beralih perguruan atau keluar sama sekali. Namun demikian mengurut dari isi Pertalekan Cimande sepanjang tidak melakukan pelanggaran, maka yang bersangkutan tetap menjadi murid TTKKDH sekalipun tidak pernah lagi melakukan latihan.

Di zaman modern ini perkembangan TTKDH Pontang mulai tergerus oleh zaman maju, banyak anak-anak yang sudah enggan melestarikan budaya lokal seperti persilatan, yang dahulu sebagai media dakwah Islam sekarang sudah mulai lunturnya masyarakat untuk melestarikan. sehingga ketua T'TKDH Kab. Serang sedang gencar-gencarnya memajukan kembali melalui media pendidikatan, yang setiap lembaga pendidikan seperti Sekolah baik SD sampai jenjang SMA terdapat ekstra-kulikuler bela diri menjadi salah satu kewajiban yang harus diikuti. Yang di resmikan oleh pemerintah daerah melalui orang nomor satu di Banten, Rano Karno Gubenur Banten.

Saat wawancara yang kami laksanakan banyak anak-anak yang sudah mengikuti dunia persilatan dari SD-SMP akan tetapi anak remaja yang seusia SMA enggan mengikutinya dengan alasan malu maupun tidak percaya diri. Selain itu perkembangan TTKDH hanya sebagai hiburan saja yang dipertunjukan saat acara-acara resmi maupun tidak resmi. Sebagai penggerak kang Mamak salah satu ketua TTKDH Kec. Pontang berinisatif memeluk remaja untuk melestarikan dunia persilatan TTKDH yang ada di pontang.

\section{Praktik ritual magi silat Tjimande}

Praktik ritual magi silat Tjimande yang pertama adanya perjanjian yang telah ditetapkan dari pendiri-pendirinya. Syarat untuk masuk angggota Tjimande:

a. Bersumpah dan membaca dua kalimat syahadat

di dalam ritual magi terdapat praktik bahwa setiap yang ingin belajar ilmu harus terlebih dahulu mengucapkan salah satu rukun Islam yang pertama, menurut ketua padepokan tjimande bahwa syahadat merupakan pendekatan diri kepada sang penciptanya sebagaimana yang sudah 
dilakukan pada agama Islam, tujuannnya lebih mempercayai bahwasanya tiada Tuhan selain Allah dan Nabi Muhammad utusan Allah.

b. Urutan

Menurut Kang Mamak salah satu pengurus TTKDH Pontang Kab. Serang urutan adalah salah satu syarat kedua dimana mempunyai filosofi yang tinggi, di dalam urutan bukan hanya untuk melenturkan tangan ataupun anggota tubuh akan tetapi juga sebagai kiasan dalam kehidupan, saat urutan juga terdapat pukulan di sini letak filosofinya saat tangan atau anggota tubuh diurut serta di pukul bibir berucap "uuhh" tanda kesakitan saat dipukul sebagai manusia berpikir yang mempunyai akal bahwa yang namanya dipukul itu akan sakit maka kita sebagai manusia yang berpikir tidak melakukan hal tersebut tanpa kecualian jika seseorang itu adalah musuh yang tidak memiliki rasa berpikir.

c. Kembang tujuh rupa, minuman tujuh rupa, makanan ringan tujuh rupa, rokok tujuh rupa, sajian tujuh rupa serta pelatihan selama tujuh malam di hari jumat. syarat yang ketiga seperti yang sudah diuraikan di atas seorang yang ingin melanjutkan tahap kanuragaannya harus mengikuti syarat pembukaan ini sebagai salah satu penghormatan kepada tujuh tokoh pendiri silat Tjimande.

d. Membaca doa (khadorot)

bukan hanya tablilan saja di dalam ilmu persilatan khususnya persilatan tjimande harus khadorotan untuk pendekatan diri kepada sang pencipta dan mempunyai kepercayaan local bahwasanya bukan hanya Allah saja sebagai pelindung akan tetapi seorang ilmu yang tinggi seperti ulama, sultan, maupun para pembesar Islam yang ada di Banten untuk pelindungan diri dari marabahaya yang sedang dihadapinya, ataupun sedang melaksanakan persilatan.

e. Olah batin

Olah batin adalah tahapan berikutnya untuk keluwesan serta keuletan yang di barengi dengan keyakinan untuk mendapatkan ilmu magi tersebut 
sehingga kepercayaan yang timbul dari diri seseorang mampu menyakinkan bahwasanya olah batin ini untuk mendekatkan diri pada sang penciptanya.

f. Mendekatkan diri kepada sang pencipta

Mengosongkan sifat buruk adalah pendekatan diri pada sang penciptanya melaui pantang-pantangan yang bersifat duniawi bernama pertalekan. Di TTKKDH setiap perguruan silat mempunyai kode etik yaitu semacam hukum perguruan yang wajib dipatuhi oleh para warganya. Kode etik tersebut sifatnya mengikat dimana pelanggaran terhadap kode etik ini akan menyebabkan si pelanggar akan terkena sanksi seperti dikeluarkan dari perguruan, tidak dibenarkan menggunakan atribut perguruan lagi, bahkan jika si pelanggar ternyata tidak perduli terhadap hukum perguruannya dimana setelah diberi hukuman masih melakukan pelanggaran lagi, terkadang sang guru atau murid yang dipercaya terpaksa turun tangan menyelesaikan masalah dengan cara menantang sipelanggar adu ilmu dengan tujuan membuatnya jera.

Demikianlah TTKKDH juga memiliki kode etik atau hukum tersendiri yang disebut Talek Cimande dan diberlakukan kepada seluruh warga perguruan dimanapun berada sepanjang masih hidup di dunia dan masih mengakui Talek Cimande merupakan pengisi dan pengekang hawa nafsu dan sifat-sifat yang dapat merugikan semua pihak. Ada sebuah pertanyaan tentang pengguanaan kata Cimande pada pertalekan ini yaitu mengapa digunakan kata "Cimande" dan bukan TTKKDH. Beberapa alasan dapat menjadi jawaban bagi pertanyaan tersebut diantaranya timbulnya rasa kekaguman maupun tanda bakti kepada asal-usul TTKKDH sehingga dalam talek ini disebut Cimande. Selain itu TTKKDH memang merupakan turunan ilmu silat Cimande sebagai dampak dari perkembangan dan persebaran ilmu silat ini yang dilakukan oleh murid-muridnya. Penggunaan tersebut juga sekaligus memperlihatkan sebuah pengakuan bagi TTKKDH yang tetap mengakui 
YANWAR PRIBADI dkk

Cimande sebagai induknya dan menjadi identitas secara umum dalam warga Cimande. ${ }^{18}$

${ }^{18}$ Adapun isi pertalekan TTKKDH adalah: 1. Kedah patuh sareng taat ka Ibu Bapak, ka guru-guru, karatu, kbususna Allab S.W.T sareng Rasulullah S.A.W. 2. Kedah sanggup bagai siswa Cimande ngalaksanakeun sholat lima waktu termasuk sunah Nabi.3. Teu kenging mibeulaan, tapi oge teu kenging kapiheulaan.4. Teu kenging ujub, ria, takabur, atanapi sum'ah. 5. Ten kenging nyela, nyaci-nyaci kana kaulinan batur pencak, nu sanes golongan Cimande. 6. Teu kenging bohong, nipu, lecor tina jangï kasaha bae. 7. Teu kenging ngulinan pamajikan batur, teu aya kacualina, keur sanaos lengoh (ka istri lengoh) oge anu sifatna ngalanggar tina kahormatan nab eta teu kenging. 8. Teu kenging nikah ka tilas dulur sapelajaran silat Cimande, upami ten aya musyawarah ti paynn. 9. Teu kenging ngalanggar M7, sapartos: Maen, Maling, Minum-minuman, Mangani, Madon, Madat, Mateni. 10. Teu kenging latiban wengi Saptu sareng dintena, wengi Senen sareng dintena. 11. Maksud guna silat Cimande ieu kanggo ngajagi Lima Bagian nyaeta: Jiwa, Agama Islam, Kaluarga, Harta, Nagara upami diparyogikeun. 12. Silat Cimande ieu pantang mundur sanaos sajungkal beas. 13. Kedah uninga kawajiban bagi para siswa Silat Cimande diwajibkeun setiap wengi Jum'at ngayakeun rurujakan (selametan), urutan, tanpa batas, oge upami tos kenging 7 Jum'at ti ngawitan lebet kedah diayakeun syukuran. Oge perlu kauninga setiap wengi Jum'at dina setiap sasib Mulud wajib dikeceran (dipeureub) sataun sakali. 14. Perlu kauninga Silat Cimande ieu teu ngagaduban peupeuban, tonjokan, sepakan sareng sajabina anu sifatna pikeun nganiaya kasasama kacuali Cindekna "Tak akan menyerang tapi bila diserang." 15. Saparangosna lebet kana Silat Cimande kedah leres-leres ngajagi nama baik. Cimande, kalayan urang kedabna bandap asor, sopan santun ngabadapkeun diri kasaba bae, keur sanaos urang dibina basa anatapi diciduban sakali dua kali mas usap bae nanging upami langkung ti kitu eta pengbinaan the ku urang kedah dibindarkeun sesuai sareng anu tilu bagian dibandap ieu: butang kedah enggal mayar, nambut kedah enggal mulangkeun, jangii kedah tepat. 16. Saparantosna lebet kana Silat Cimande kedah leres-leres ngangkeun dulur saibu sabapak. Hal ieu anu cocok pisan sareng sabda Nabi anu pibartoseunnana kirang langkung kieu: Karunya kadiri dulur the kedab karunya sapartos kadiri urang sorangan. 17. Perbatosan: Sanggup atanapi keunteu mentaati Talek anu kasebat dilubur bieu?. 18. Sangsi-sangsi: Upami salah sabiji anggota pelajar Silat Cimande ngalanggar tina salah sabijina Talek anu kasebat dilubbur bieu maka Pelatib ten tanggung jawab. 19. Sakitu pertalekan Silat Cimande sebagai garis ageungna pamugi diamalkeun sakumaba anu dimaksad dilubur bieu kalayan Talek anu ieu tos disabkaeun ku para sesepub Silat Cimande. 20. Talek ieu disusun tur disebar luaskeun kapara pelajar Silat Cimande di seluruh tanah air. 


\section{Tanggapan Masyarakat Dalam Hal Ritual Magi}

Di Desa Kesabilan Kecamatan Pontang Kabupaten Serang-Banten saat mewawancari setiap masyarakat kampung tersebut banyak yang mengatakan di dalam dunia persilatan banten masih menggunakan ilmu di luar pikiran akal pikiran manusia seperti halnya menjadikan kekebalan pada anggota tubuh dari senjata tajam.

Menurut salah satu masyarakat setempat, magi adalah salah satu penghubung manusia terhadap sang pencipta dimana saat zaman 90an ilmu magi di gunakan untuk menjaga diri dari musuh yang siap menyerang, ilmu tersebut bekal dalam mempertahankan diri dari dunia luar. Bukan hanya mempertahankan diri ilmu magi pun di gunakan sebagai ladang dakwah penyebaran agama Islam melalui ritual local antara budaya dengan agama, sehingga menjadi kesatuan.

Ada yang menarik dari pendapat masyarakat Islam yang diangkat menjadi tanggapan di materi pembahasaan ini, bu neneng (32) ia salah satu anggota dimana masa remajanya mengikuti silat tjimande di TTKDH Pontang, ia memaparkan ritual magi perlu digunakan karena sebagai syarat masuknya di dunia persilatan TTKDH Pontang, menurutnya magi ini tidak mengandung kesyirikan terhadap sang pencipta akan tetapi hanya sebagai syarat saja melalui media ritual magi.

4. Manfaat dari ritual magi

a. Lebih mendekatkan diri pada Allah SWT.

Tarekat adalah salah satu pendekatan diri pada sang pencipta, ritual magi pun lelalui pendekatan pada sang pencipta melalui dengan mengkosongkan hati dari sifat buruk, keji, dan mungkar. Dengan ritual magi ini sebagai media pendekatan

b. Untuk kesehatan jasmani

Di dalam kesenian TTKDH ini tidak lepas dari olah rasa, olah jiwa, dan olah raga (fisik) kebugaran jasmani perlu di latih bukan hanya berolah raga akan tetapi pula silat media olah fisik dimana setiap sendi, saraf serta tulang dilatih agar lebih pleksibel, gerakan-gerakan silat tidak lepas dari olah raga, sehingga kebugaran tubuh selalu terjaga 
c. Bela diri

Pada zaman dahulu sampai zaman sekarang persilatan adalah salah satu media untuk mempertahankan hidup, manusia perlu pertahanan. Di zaman modern ini manusia perlu waspada terhadap ancaman dunia luar, sehingga persilatan menjadi patokan untuk pelatihan.

d. Media hiburan

Indonesia tidak lepas dari seni, adat, tradisi, dan budaya. silat adalah salah satu kesenian atau warisan leluhur bangsa Indonesia yang harus di pertahankan dari perkembangana zaman yang modern ini, untuk menjaga kesenian persilatan silat dijadikan suatu pertunjukan ataupun hiburan bagi masyarakat, dunia persilatan yang identic untuk mempertahankan diri dari dunia luar ataupun musuh serta ajang dakwah penyebaran agama Islam sekarang tergantikan menjadi suatu pertunjukan masyarakat lokal yang selalu di tanggap pada hari-hari tertentu atapun acara tertentu.

e. Mempererat tali silaturahmi

Manusia adalah makhluk sosial, tidak lepas dari manusia lainnya bukan hanya gotong royong, bakti sosial, bertamu serta kesosialan lainnya, dunia persilatan pun sebagai ajang mempererat kekerabatan antar masyarakat baik lapisan bawah, menengah, maupun atas. Semuanya menjadi kesatuan untuk menjujung kekerabatan. 


\section{Daftar Pustaka}

Ayubi, Sholahuddin Al, 2012. MAGI di Lingkungan Pesantren Studi Magi Kitab Mujarrabat al-Dairabi al-Kabir di Pondok Pesantren Salafiyah Banten, Banten, Serang: FUDAPress. ,2009. Agama dan Budaya, FUDA: IAIN Banten.

Humaeni, Ayatullah, 2013. Akulturasi Islam dan Budaya Lokal dalam Magi Banten, Jakarta: UIN Syarif Hidayutullah.

KKBI pengertian Magi.

Mansun, Syafi'in, 2009. KULLAH Aliran Kebatinan, Banten, Serang: FUDA Prees.

Suandi, Ahmad, Ketua Padepokan TTKDH Pontang.

Sugiyono, 2015. Metode Penelitian Kuantitatif, Kualitatif, dan R\&B, Bandung: Alfabeta.

Suparni (70th) desa Kesabilan Pontang.

Sutandi, Rudi, Kepala Desa Kesabilan, Data Sekunder Kelurahan Kesabilan. 